\title{
Case report of amniotic membrane derived-stem cells treatment for feline chronic obstructive pulmonary disease
}

\author{
Taeho Kim ${ }^{1,2}$, Seul Ah $\mathrm{Noh}^{1,2}$ and Junguk Jü ${ }^{1,2, *}$ \\ ${ }^{1}$ AniCom Therapeutics Inc., Seoul 04599, Korea \\ ${ }^{2}$ AniCom Medical Center, Animal Hospital, Seoul 04599, Korea
}

Received November 23, 2021

Revised December 7, 2021

Accepted December 8, 2021

\section{*Correspondence}

Junguk Ju

E-mail: fire0809@gmail.com

Author's Position and Orcid no.

Kim T, PhD,

https://orcid.org/0000-0002-1354-7019

Noh SA, MS,

https://orcid.org/0000-0002-9335-0725

Ju J, MS,

https://orcid.org/0000-0002-9442-1548

\begin{abstract}
A cat who is a 15-year-old and spayed female visited an animal clinic with severe coughing symptoms. Since the cat's coughing symptoms had worsened from the age of 10 and X-rays showed a bronchial pattern in the lungs, it was diagnosed as Chronic Obstructive Pulmonary Disease (COPD). She received three injections of stem cells isolated from the amniotic membrane on days 0,7 , and 23 . Although there was no improvement in the clinical findings on the x-ray, the number of coughing was significantly reduced. In addition, even after long-term follow-up post treatment for a month, she was stable with almost no coughing.
\end{abstract}

Keywords: amnion, COPD, feline, stem cells

\section{INTRODUCTION}

Chronic obstructive pulmonary disease (COPD) has emerged as a serious public health concern in recent years and is predicted to become the fourth leading cause of death worldwide by 2030 (Mathers and Loncar, 2006). COPD of the feline is treated with medications including bronchodilators, inhaled steroids, oral steroids, phosphodiesterase -4 inhibitors, theophylline, and antibiotics; lung therapies, such as oxygen therapy and pulmonary rehabilitation programs; and surgeries including lung volume reduction surgery, lung transplantation, and bullectomy. However, these treatments have limited efficacy and serious side effects (McEvoy and Niewoehner, 1997; McEvoy and Niewoehner, 2000; Chang et al., 2019).

There have been several reports in the literature recently using stem cells to treat lung-related diseases. In the murine asthma model, Th2-related cytokines were decreased to maintain Th1/Th2 balance after mesenchymal stem cells injection, thereby regulating immunity (Nemeth et al., 2010; Park et al., 2010; Kavanagh and Mahon, 2011). In feline asthma, stem cell therapy reduced lung attenuation compared to an untreated stem cells in the asthmatic cat (Trzil et al., 2016).

In this study, we treated a COPD cat using amniotic membrane-derived stem cells, which have similar stemness to mesenchymal stem cells but are non-invasively and easily obtainable with large amounts.

\section{CASE REPORT}

A 15-year-old, neutered female cat weighing $4.6 \mathrm{~kg}$ was diagnosed with COPD at the age of 10 with a severe cough. Clinical symptoms were coughing, gagging, and breathing difficulty more than 10 times every day. X-rays showed a bronchial pattern throughout the lung field, a 
typical aspect of COPD (Fig. 1A). We counted the number of coughs per day; a cough was regarded when she started a coughing and it continuously maintained. Sometimes she has breathing difficulty after severe coughing. She was treated with antibiotics and prednisolone when she had severe coughing. Usually she was given doxycycline as antibiotics (5 mg/kg twice a day) and prednisolone to suppress immune system ( 1 to $5 \mathrm{mg} / \mathrm{kg}$ twice a day). However, the effect of the medicine was decreased and finally
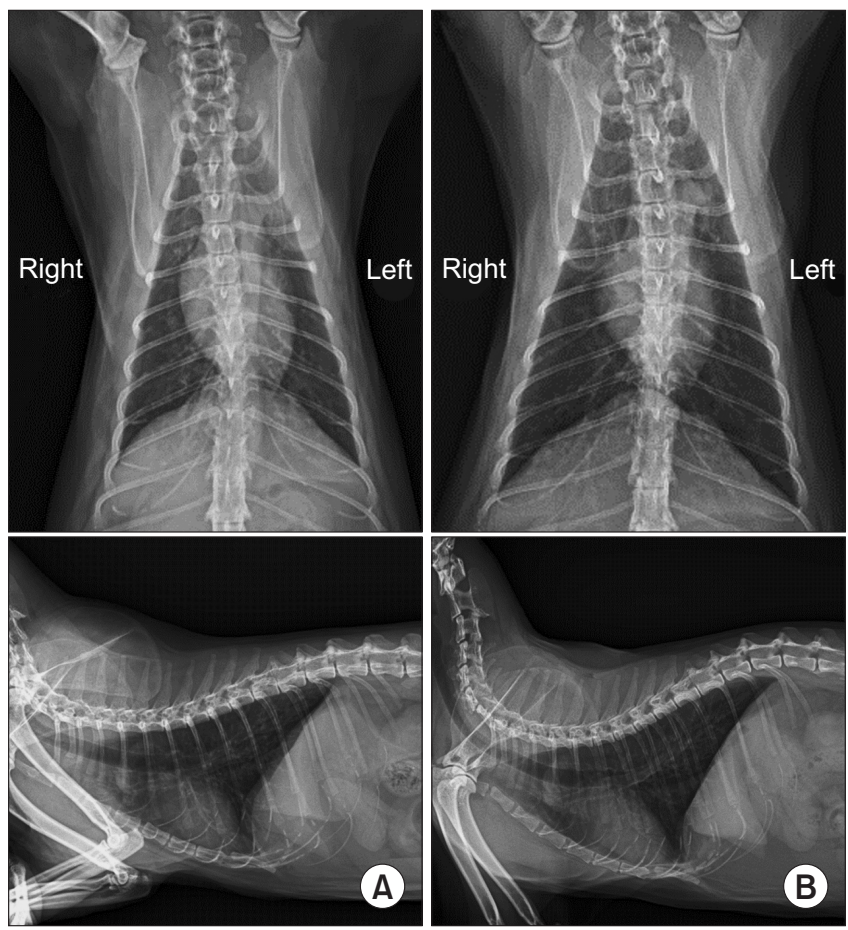

Fig. 1. Chest $X$-ray results of COPD cat. Chest $X$-ray before stem cell treatment and after conventional drug treatment (A). Chest X-ray after one week of stem cell transplantation (B). was non-responsive. Therefore, stem cell therapy was performed 3 times on days 0,7 , and 23 .

Stem cells from the feline amniotic membrane were isolated by referring to the method (Fig. 2A). Briefly, we obtained amniotic membranes during the cesarean section surgery on full term pregnancy (60 days). The feline placenta was washed with sterile phosphate buffered saline (PBS), thereafter, the amniotic membrane was mechanically separated from the allantoic sac, and enzymatic digestion was performed using $0.1 \%$ collagenase solution to isolate amniotic-derived mesenchymal stem cells (Vidane et al., 2014).

The patient was premedicated with cefazolin $(25 \mathrm{mg} /$ $\mathrm{kg}$ intravenously) and dexamethasone $(0.1 \mathrm{mg} / \mathrm{kg}$ intravenously) prior to stem cell transplantation, thereafter, allogeneic stem cells were infused intravenously. The $1 \times 10^{6}$ cell $/ \mathrm{kg}$ stem cells were mixed in normal saline with $200 \mathrm{IU}$ heparin sulfate and administered intravenously with a syringe pump-operating with $10 \mathrm{~mL} / \mathrm{kg} / \mathrm{hr}$ injection speed. The dose was based on previous studies, and proved not to be associated with adverse events as well (Quimby et al., 2013; Noh et al., 2021). The patient appeared clinically normal and stable during and after infusions.

The patient coughed an average of 3 to 25 times a day before stem cell transplantation. There was no clincal improvement in chest X-ray examination after 1 week of stem cell treatment (Fig. 1B), but the number of coughs was significantly reduced to once or not a day (Fig. 2B) and there were no side effects like hypersensitivity, vomiting, throat pain, bleeding, pneumonae, and graft failure. Appetite and activity were clinically improved compared to before stem cell transplantation and there was no dys-
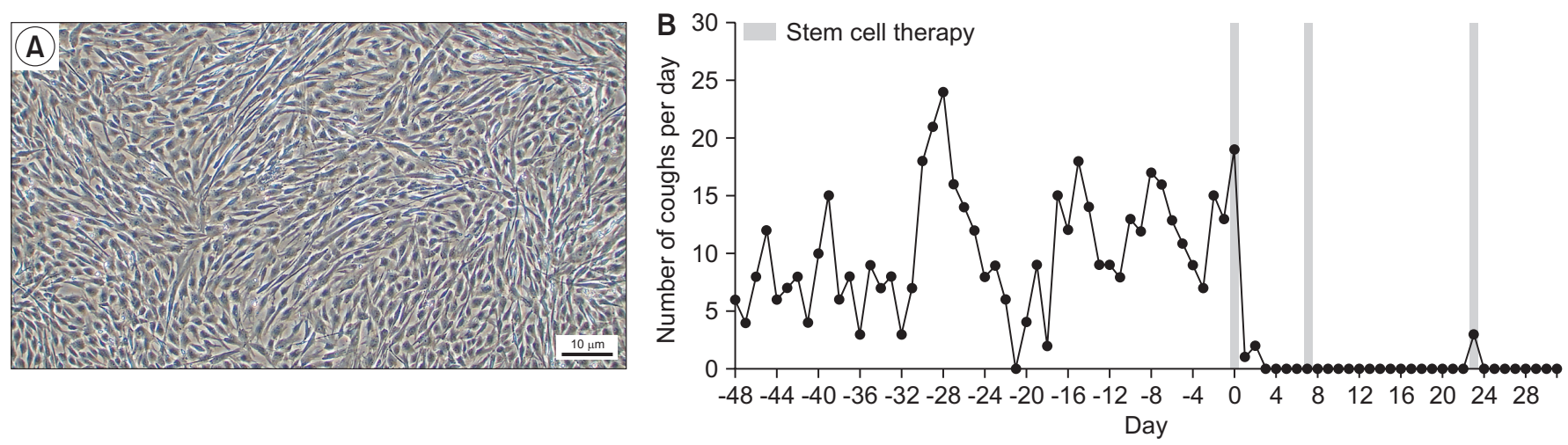

Fig. 2. Stem cells used for the treatment of COPD therapy and coughing index. Morphology of mesenchymal stem cell isolated from cat amniotic membrane (A). Coughing index in patients with COPD. After stem cell therapy, the frequency of coughing decreased sharply (B). 
pnea or nausea. Later on, she additionally had 6 times stem cell transplants after a month of first transplantation series, and we observed the patient post stem cell transplantation for 6 months and confirmed that there was no longer any coughing.

\section{DISCUSSION}

Stem cell transplantation in animal models of COPD has in vivo safety, immunogenicity, pharmacokinetics, and therapeutic value in many cases of preclinical studies. In addition, various tissue-derived stem cells were safe and effective for intravenous and intratracheal injection in animal models of COPD (Liu et al., 2016). In our case report, we could see a big improvement after a transplantation of stem cell, and additionally appetite was also increased compared to before the stem cell therapy. The immunomodulation and anti-inflammatory abilities of stem cells are thought to be important in the treatment of COPD

Chronic inflammation is known to be a major cause of COPD, asthma, and interstitial lung disease (ILD). Immunomodulation and anti-inflammatory abilities of mesenchymal stem cells are effective in the treatment in various animal models. When bone marrow-derived stem cells were transplanted in a COPD mouse animal model, proinflammatory mediators including TNF- $\alpha$, IL- $1 \beta$, MCP-1, and IL- 6 and proteases such as MMP9 and MMP12 were down-regulated, and VEGF and its receptors were upregulated (Guan et al., 2013). Antiapoptotic properties of mesenchymal stem cells increased cell proliferation in the damaged area and improved the pulmonary vascularity, which is followed by restoring emphysema (Zhen et al., 2010; Huh et al., 2011). Mesenchymal stem cells also reduced Th2-associated cytokines to maintain Th1/Th2 balance and promote immune tolerance through Treg proliferation (Nemeth et al., 2010).

The amnion is a valuable source which a large number of stem cells can be easily obtained by a non-invasive method and is the similar stemness of mesenchymal stem cells (De Coppi et al., 2007). Since allogeneic mesenchymal stem cells lack the expression of MHC I and MHC II and have immune tolerance in allografts, they can be safely used in clinical practice (Patel et al., 2008; Lee et al., 2011). The amniotic membrane-derived stem cells also have the aforementioned benefits and can be widely used for animal stem cell therapy.

\section{CONCLUSION}

In this study, the cat has great improvement clinically by stem cell transplantation rather than conventional drug treatment in cat with COPD. As we know, COPD for cats and human is difficult to be treated without continuous medicine such as immune suppressants. The medicine potentially has side effects and inconvenience. In addition, life quality would be worsen with medicine. Therefore, stem cell transplantation will be another great solution for respiratory disorders in humans and animals.

Author Contributions: Conceptualization, T.K. and J.J.; data curation, T.K. and J.J.; formal analysis, S.A.N. and J.J.; funding acquisition, J.J.; investigation, J.J.; methodology, J.J.; project administration, J.J.; resources, S.A.N. and J.J.; software, T.K.; supervision, J.J.; validation, J.J.; visualization, S.A.N. and T.K.; writing - original draft, T.K. and J.J.; writing - review \& editing, T.K. and J.J.

Funding: This study was supported by grants from the National Research Foundation of Korea (NRF2019M3A9H1103582).

Ethical Approval: Not applicable.

Consent to Participate: Not applicable.

Consent to Publish: Not applicable.

Availability of Data and Materials: Not applicable.

Acknowledgements: None.

Conflicts of Interest: No potential conflict of interest relevant to this article was reported.

\section{REFERENCES}

Chang YP, Lai CH, Lin CY, Chang YC, Lin MC, Chong IW, Sheu CC, Wei YF, Chu KA, Tsai JR, Lee CH, Chen YC. 2019. Mortality and vertebral fracture risk associated with long-term oral steroid use in patients with chronic obstructive pulmonary disease: a systemic review and meta-analysis. Chron. Respir. Dis. 16:1479973119838280. 
De Coppi P, Bartsch G Jr, Siddiqui MM, Xu T, Santos CC, Perin L, Mostoslavsky G, Serre AC, Snyder EY, Yoo JJ, Furth ME, Soker S, Atala A. 2007. Isolation of amniotic stem cell lines with potential for therapy. Nat. Biotechnol. 25:100-106.

Guan XJ, Song L, Han FF, Cui ZL, Chen X, Guo XJ, Xu WG. 2013. Mesenchymal stem cells protect cigarette smoke-damaged lung and pulmonary function partly via VEGF-VEGF receptors. J. Cell. Biochem. 114:323-335.

Huh JW, Kim SY, Lee JH, Lee JS, Van Ta Q, Kim M, Oh YM, Lee YS, Lee SD. 2011. Bone marrow cells repair cigarette smokeinduced emphysema in rats. Am. J. Physiol. Lung Cell. Mol. Physiol. 301:L255-L266.

Kavanagh H and Mahon BP. 2011. Allogeneic mesenchymal stem cells prevent allergic airway inflammation by inducing murine regulatory T cells. Allergy 66:523-531.

Lee H, Kang S, Park S, Lee S, Lee H, Koh P, Park J, Paik W, Yeon S. 2011. Expression of HLA and mixed lymphocyte reaction of mesenchymal stem cells derived from human umbilical cord blood. J. Vet. Clin. 28:399-402.

Liu X, Fang Q, Kim H. 2016. Preclinical studies of mesenchymal stem cell (MSC) administration in chronic obstructive pulmonary disease (COPD): a systematic review and metaanalysis. PLoS One 11:e0157099.

Mathers CD and Loncar D. 2006. Projections of global mortality and burden of disease from 2002 to 2030. PLoS Med. 3:e442.

McEvoy CE and Niewoehner DE. 1997. Adverse effects of corticosteroid therapy for COPD. A critical review. Chest 111:732743.

McEvoy CE and Niewoehner DE. 2000. Corticosteroids in chronic obstructive pulmonary disease. Clinical benefits and risks. Clin. Chest Med. 21:739-752.

Nemeth K, Keane-Myers A, Brown JM, Metcalfe DD, Gorham JD, Bundoc VG, Hodges MG, Jelinek I, Madala S, Karpati S,
Mezey E. 2010. Bone marrow stromal cells use TGF-beta to suppress allergic responses in a mouse model of ragweedinduced asthma. Proc. Natl. Acad. Sci. U. S. A. 107:56525657.

Noh SA, Kim T, Ju J. 2021. Case reports of amniotic membrane derived-cell treatment for feline chronic renal failure. J. Anim. Reprod. Biotechnol. 36:116-120.

Park HK, Cho KS, Park HY, Shin DH, Kim YK, Jung JS, Park SK, Roh HJ. 2010. Adipose-derived stromal cells inhibit allergic airway inflammation in mice. Stem Cells Dev. 19:1811-1818.

Patel SA, Sherman L, Munoz J, Rameshwar P. 2008. Immunological properties of mesenchymal stem cells and clinical implications. Arch. Immunol. Ther. Exp. (Warsz.) 56:1-8.

Quimby JM, Webb TL, Habenicht LM, Dow SW. 2013. Safety and efficacy of intravenous infusion of allogeneic cryopreserved mesenchymal stem cells for treatment of chronic kidney disease in cats: results of three sequential pilot studies. Stem Cell Res. Ther. 4:48.

Trzil JE, Masseau I, Webb TL, Chang CH, Dodam JR, Liu H, Quimby JM, Dow SW, Reinero CR. 2016. Intravenous adipose-derived mesenchymal stem cell therapy for the treatment of feline asthma: a pilot study. J. Feline Med. Surg. 18:981-990.

Vidane AS, Souza AF, Sampaio RV, Bressan FF, Pieri NC, Martins DS, Meirelles FV, Miglino MA, Ambrósio CE. 2014. Cat amniotic membrane multipotent cells are nontumorigenic and are safe for use in cell transplantation. Stem Cells Cloning 7:71-78.

Zhen G, Xue Z, Zhao J, Gu N, Tang Z, Xu Y, Zhang Z. 2010. Mesenchymal stem cell transplantation increases expression of vascular endothelial growth factor in papain-induced emphysematous lungs and inhibits apoptosis of lung cells. Cytotherapy 12:605-614. 